\title{
Incidence of Listeria monocytogenes in Bovine Environment with Respect to Phenotypic and Genotypic Characterization: A Review
}

\author{
Shubhangi Warke* and V.C. Ingle \\ Department of Veterinary Microbiology and Animal Biotechnology $T \& R C$, Nagpur \\ Veterinary College, MAFSU, Nagpur, India \\ *Corresponding author
}

\section{A B S T R A C T}

Ke ywords

Monocytogenes, Bovine, Phenotypic character

Article Info

Accepted:

30 October 2019

Available Online:

10 November 2019
Listeria is an ubiquitous organism and can be isolated from a variety of sources from different parts of the world.Various methods are used to sanitize the bovine and food processing environment and to control the organism from bovine environment.Proper surveillance, rapid detection of Listeria is important to ensure the safety.The article reviews major Listeria monocytogenes incidences in bovine and their environment.

\section{Introduction}

The genus Listeria is currently grouped into 17 species identified as Listeria monocytogenes, L. ivanovii, L. marthi, $L$. innocua, L. fleischmanni, L. aquatica, $L$. newyorkensis, L. rocurtiae, L. weihenstephanensis, $L . \quad$ grandensis, $L$. booriae, L. seeligeri, L. welshimeri, L. grayi, L. floridensis, L. comellensis and L. riparia. Listeria are small rod shaped and Gram positive bacteria. Out of 17 species, two species viz. L. monocytogenes and L. ivanovii have been recognized as pathogenic. $L$. monocytogeneshas now recognized as a facultative intracellular pathogen, accountable for a number of foodborne human infections that lead to invasive disease of high fatality rate (25 to $30 \%$ ). Listeriosis is highly prevalent in human as well as in farm ruminants (sheep, cattle, goats).In USA, listeriosis ranks third among foodborne infections associated with mortality (Scallan $e t$ al., 2011).

L. monocytogenes is prevalent in products such as water, sludge, vegetation, feed, food, plants, soil, and milk products in a number of geographical regions (Leite et al., 2006). It also transmits from infected humans and animals (Liu, 2008; Dhama et al., 2013). About $11-52 \%$ of infected animals remain as healthy fecal carriers of the pathogens (Rocourt and Cossart, 1997). 
L. monocyotgenes becomes potent pathogen as it can survive in the bio-film and can sustain temperatures as low as $-1.5{ }^{\circ} \mathrm{C}$ to as high as $50^{\circ} \mathrm{C}$ and tolerates a $\mathrm{pH}$ between 4.3 and 9.6. Once an area gets contaminated by this organism, its irradication becomes difficult (Rodriguez et al., 2008). Listeria is also prevalent in dairy environment (Nightlingale et al., 2004). Spread of listeria between animals or human generally starts from cattle farm which acts as a major source of transmission (Pritchard and Donnely, 1999).Farm ruminants are regularly exposed to Listeria sp. through a continous fecal- oral cycle (Vazquez-Boland et al., 2001). Silage feeding has been reported to increase the listeria exposure in ruminants (Donnelly, 2002).

L.monocytogenes has been reported as a milk contaminant from mastitic animals. It is responsible for mastitis in cattle along with evident abortion, infertility, repeat breeding, encephalitis and septicemia (Barbuddhe et al., 2008; Deb et al., 2013). In a cattle farm, prevalence of Listeria is reported to be on higher side especially in feed bunks, feedings and water trough. Moreover, cattle feces and silage are found to be the major sources of $L$. monocyotogenes infection (Yoshida et al., 1998). Sepsis, nervous and listerial abortion are three common forms of listeriosis based on symptoms (Carare, 2006). In ruminants, L.monocyotgenes has also been responsible for encephalitis and uterine infections

In early years, it was found to be tough to correlate the epidemiology of $L$. monocytogenes in cow as no such method was available and hence reports were mostly on lower side (Fenlon, 1986b). In recent time, PCR based detection of $h l y \mathrm{~A}, \operatorname{act} \mathrm{A}, p l c \mathrm{~A}$ and inlB gene assist in easy detection of $L$. monocytogenes (Winters et al., 1999 and Yong et al., 2003). In addition, serotyping further adds the details to characterize $L$. monocytogens with respect to virulence and pathogenicity (Douminth et al., 2004). Molecular typing of L.monocytogenes serotypes assist in quick detection of isolates involved in disease outbreaks and thus adds to the efficiency of diagnosis (Hofer et al., 2000). At present pulse field gel electrophoresis scores a high rank in detection and phylogenitic analysis of $L$. monocytogenes. The method is featured by high discriminatory power, being reproducible and easily gets standardized and proved specific at genetic level (Swaminathan et al., 2001 and Connor et al., 2010).

Being a pathogen L. monocyotgenes featured with biofilm formation for its survive bility in the environment (Jeong and Frank, 1994). In a surviving instinct, L. monocytogenes has found to be resistant to commonly used disinfectants which are generally used in dairy and food plants. Despite of using rigorous protocol of disinfection, L.monocytogenes is found to be a milk contaminant especially in farm conditions.

Recently due to the awareness towards food safety, it is important to develop suitable methods which could be specific, reliable and rapid since many traditional methods lack sensitivity, specificity and rapidity.

Furthermore Real time PCR (qPCR) technique is advantageous by ruling out the many limitations of conventional methods and also lowers the risk of cross contamination. qPCR method is surely a fast and the results show increasing response once positive sample recorded and also post PCR processing is not required which makes it an easy tool for detection.

A number of studies reported the occurrence of listeria species in India from various sources (Dhanashree et al., 2003; Manoj et al., 1991; Moharem et al., 2007; Kalorey et al., 
2008; Jallewar et al., 2007; Yadav et al., 2011). Poor understanding and lack of awareness on Listeriosis in India, the $L$. monocytogenes infection goes unnoticed especially in human and animals. In India, the data do not represent the clear picture of its epidemiological scenario. Not many reports are available for the source of $L$. monocytogenes contamination.

\section{Listeria}

Species in Listeria are very well known as non spore forming, facultative anaerobic rods, non capsulated organism. They measur about 0.4 by 1 to $1.5 \mu$ in size and motile at 10 to $25^{\circ} \mathrm{C}$ as reported by Sallen et al., (1996) and Rocourt, (1999). Listeria sp. are sometimes found to be positive for the mucopolysaccharides capsule along with catalase positive nature as reported by Smith and Metzger (1962). This large group of Listeria genus is recognized by seventeen well known species, $L$. monocytogenes, $L$. welshimeri, L. marthii, L. innocua, L.grayi, L.seeligeri, L. ivanovii, L. fleischmannii, L.floridensis, L. aquatic, L. newyorkensis, $L$. cornellensis, L. rocourtiae, $L$. weihenstephanensis, L. grandensis, L. riparia, and L. booriae. Among them only two are genetically pathogenic, L. monocytogenes and L. ivanovii as reported by Henkeet al., (2015). A very first report of the pathogenicity with $L$. monocytogenes has been recorded way back in 1926 (Murray et al., 1926) and recently $L$. monocytogenes has been listed in the food borne pathogen category by World Health Organization (WHO, 2002) making it more featured organism to investigate.

\section{Listeria monocytogenes}

Among Listeria species, L. monocytogenes dominates in pathogenicity and recognized with food borne bacterial zoonotic disease (Ben Embarek, 1994). It is found to be infecting wider range of hosts like cattle, chicken, goat, and sheep and comes out with disease, listeriosis in high risk group hosts, pregnant women, neonates and even immunocompromised adults which puts up a serious concern about its spread and prevalence in different ecology (Schuchat et al., 1992). With about 0.2 to 0.8 cases per 100,000 persons reported with infection (Gellin et al., 1991, McLauchlin 1996, Kela and Holmstrom, 2001, Lukinmaa et al., 2003); according to research of Dalton et al., (1997) among infected population progression of sepsis, meningitis, abortion, and gastroenteritis is very common and in total, mortality rate reaches close to 20 to $30 \%$, hence making it a serious pathogen (Goulet et al., 1998). Keeping in view, origin of pathogen always remain the concern as sometimes it may lead to sporadic or even epidemic disease situation as reported in United states. This may sometimes put up the situation of food product recall and hence creates the public health concern (Borucki et al., 2004).

Not only are the animals, human also is the host for L. monocytogenes causing human listeriosis, a potentially fatal food borne infection especially in European countries (Goulet et al., 2008; Smith and Osborn, 2009). In India, incidences of Listeriosis has extensively been reported by Malik et al., (2002) and undoutedly responsible for many abortions and premature birth in human (Bhujwala, et al., 1974). In recent time, India has accounted prevalence of $L$. monocytogenes in women with poor obstetrics history also (Gupta et al., 2003; Dhanashree et al., 2003; Kaur et al., 2007; Sonegaokar, 2009; Dixit, 2013).

L. monocytogenes is not only remain restricted to food items like raw and ready to eat produces but also recovered from fecal samples of healthy population (Gilbert et al., 1989; Sheridan et al., 1994; Wesley, 1999). With a apparent presence in fish, squid and 
crustaceans as detailed by Miettinen and Wirtanen (2005), incidence of $L$. monocytogenes also been recorded in animals with mastitis, reproductive disorders and septicaemia (Shakuntala et al., 2006; Rawool et al., 2007). L. monocytogenes additionally putting up a serious question in front of us as they are showcasing now recurrent presence in the regularly consumed meat and milk of goats, sheep and buffaloes, and from seafood especially in India as reported by Barbuddhe et al., 2000; Barbuddhe et al., 2002; Karunasagar and Karunasagar, 2000; Parihar et al., 2007).

\section{Prevalence of Listeria monocytogenes}

\section{Prevalence of L.monocytogenes from bovine environment}

Like any other pathogen, L. monocytogenes certainly spansseveral niches throughout the world such as forest soil, mud, feed, feeding grounds, birds, wildlife faeces and other as reported by Weis and Seeliger, (1975). According to Ueno et al., (1996) and Borucki et al., (2004) farm animals and farm environment also carries L. monocytogenes and act as potential source of human listeriosis. Allerberger and Wagner, (2010) proposed that bacterium can easily transmit through consumption of contaminated food, water and feed and also related this incidences with type of food production technology used which makes food "Listeria-risk foods". Cattle with $9.4 \%$ detection of $L$. monocytogenes puts up a serious question about health profile of cattle used for milk (Atil et al., 2011). Gelbíčova and Karpiskova (2012) reported 11 $\%$ sample prevalence in faeces, feed, water and environment of cattles for $L$. monocytogenes. Esteban et.al.,(2009)reported occurrence of L.monocytogenesin dairy farm environment, $46.3 \%$ prevalence of $L$. monocytogenes was reported in dairy cattle.

In one report Santorum et al., (2012) evidenced that L. monocytogenes easily getting transmitted via., farm effluents, along with feed and food also to the nearby animals and plant materials.

In India, Sarangi and Panda (2012) corroborated the L. monocytogenes presence in environmental and clinical samples of cattle, sheep, goat, poultry and pig and mostly cattle found to be positive for the species. Soil containing L. monocytogenes also been reported in Kerala by Kumar et al., (2014).Raorane et al., (2014) recorded 12\% prevalence in clinic and farm environment and Soni et al., (2014) observed L. monocytogenes was also dominating close to the soil.

\section{Prevalence of $L$. monocytogenes from animal clinical cases}

Nightingale et al., (2004) put us a concern about dispersal of L. monocytogenes from farm environment and Vidic et al., (2007) confirmed the $1.2 \%$ positivity for the listeriosis.Silva et al., (2009) also confirm the presence of L. monocytogenes in cattle aborted fetus with $2.39 \%$. Barkallah, et al., (2014) confirmed the L. monocytogenes $(4.66 \%)$ in bovine abortion of Tunisian dairy cattle.

Srivastava et al., (1985) and Shakuntala et al., (2006) confirmed the presence of $L$. monocytogenes in farm animals suffering from various reproductive disorders when tested for the fecal, nasal, vaginal swabs and blood samples with 4.4 and $7.4 \%$ prevalence of $L$. monocytogenes and other Listeria sp, respectively. Presence of $L$. monocytogenes in milk furthermore been confirmed by the PCR by targeting the $h l y \mathrm{~A}$ gene of $L$. monocytogenes with about $17.9 \%$ positive samples (Parihar et al., 2007). Animal tissue samples from cases of abortion, repeat breeding, retention of placenta also been used to confirm the presence of $L$. monocytogenes and about 16samples was recorded positive out of 359 sampled (Chopra et al., 2012). Not only L. monocytogenes $12(5.11 \%)$, remain 
present in animal samples but also the other species such as L. innocua 11(5.11\%), L. seeligeri $2(0.93 \%)$, L. ivanovii $2(0.93 \%)$, and L. welshimeri $1(0.46 \%)$ was recorded (Raorane, et al., (2014). The prevalence of L.monocytogenes in cattle is higher in contrast to other animals reported by Dixit (2013).

\section{Prevalence of L. monocytogenes from milk}

Presence of L. monocytogenes found to be variable in percent incidences across the world. As per Schlegelova et al., (2002) only two samples found to be positive out of 111 milk samples tested which accounts for $1.8 \%$ contamination for L. monocytogenes. According to Kessel (2004) in U.S dairy total 861 bulk tank sample when tested, they recorded 21 samples found to be positive. Centinkaya et al., (2014) confirmed the presence of L. monocytogenes in milk and dairy products when tested 512 food samples overall.

Presence of Listeria species has been detected in number of milk and milk products in India such as ice cream (Pednekar et al., 1997), raw milk (Bhilegaonkar et al., 1997). Kalorey et al., (2008) reported that about $5.1 \%$ of milk samples from dairy having presence of $L$. monocytogenes along with other Listeria species. Not only the milk and its products, but also the appliances used in dairy was reported to contaminated with $L$. monocytogenes such as raw milk collector, milk silos, butter milk miner and other as reported by Doijad et al., (2011). Many authors published the similar incidences of prevalence of L. monocytogenes in milk (Soni et al., (2013), Nayak et al., (2015), Yadav et al., (2010), Najand et al., (2015) and Sawantet al., (2016).

\section{Molecular characterization of $L$. monocytogenes}

With the implicit severity of $L$. monocytogenes as it is prevailing in many food products that human consumes, early or easy detection of contamination certainly is a need of an hour and in requirement number of protocols or methods have been put forward. Since the food industry demands early detection of contaminant, so that food could be either dispatched or discarded at early time, techniques like PCR making its presence which is not only sensitive but also remained to be specific to its target.

In the present scenario, detection of $L$. monocytogenes by PCR could be achieved by targeting the number of virulent genes (e.g., $h l y \mathrm{~A}, \operatorname{prf} \mathrm{A}$ and $\operatorname{act} \mathrm{A})$ which are one kind of marker genes for easy detection of Listeria monocytogenes in intramammary origin (Warke et al., 2007). In India and abroad number of stories has been written with these genes for achievement in PCR amplification for contaminated samples like fish, poultry, and wild life (Gunjal, 2006; Kalorey et al., 2006; Jellewar et al., 2007).

\section{Virulence factors of $L$. monocytogenes plc's (Phospholipase)}

L. monocytogenes posses two phospholipase 1) phosphatidyl inositol- specific PLC (PIPLC or PLC-A; encoded by plc A) and a broad range phosphatidyl choline- specific PLC (PC-PLC or PLC-B; encoded by plc B). Protein PI-PLC is a $33 \mathrm{kDa}$ protein encoded by $p l c \mathrm{~A}$ gene which is one of the six genes located in small chromosomal virulence cluster and positively been regulated by prfA gene (Portnoy et al., 1992; Bannam and Goldfine, 1999). It functions to escape pathogen from primary defense of phagocytic vacuole (Kiarsfel et al., 1994, Marquis et al., 1997), as well as from double membrane secondary vacuole (Smith et al., 1995), and assist in cell to cell spread (Kiasrsfel et al., 1994) and hence noted as essential virulence factor (Moser et al., 1997). 


\section{$h l y$ (previously called $h l y$ A and lis A)}

hlyA gene is known for encoding Listeriolysin O (LLO). LLO act by pore forming toxin, for lysing the vacuolar membrane in the host cell, resultant evading $L$. monocytogenes escapes from vacuole (Lhopital et al., 1993). Probably for the first time, Paziak - Domanska et al., (1999) standardized the PCR protocol for hlyA gene of $L$. monocytogenes having total amplicon of 731 base pairs. Further it has been proven by nested PCR and Hind I digestion to strongly support the primers and its specificity.

\section{$\operatorname{act} \mathrm{A}($ previously called prt B)}

In a recent research titles, sure attention has been put forward towards actA gene as it is essential for L. monocytogenes transmission from one cell to another by formation of listeriopods. This gene function in a way that pathogens avoid direct contact with antibodies or other immuno agents and reaches safety to neighboring cells (Kocks, 1992).

\section{iap(Invasion associated protein)}

Invasion associated protein gene (iap) found to be involved in cell division of $L$. monocytogenes and also been the important protein in phagocytosis of L. monocytogenes (Kuhn and Goebel, 1989). Any mutation in 'iap gene' may lead to the decrease in invasiveness of $L$. monocytogenes which makes it important in survival of this pathogen in host (Sun et al., 1990). As gene iap expression is not dependent on prf A (Bubert et al., 1997) but certainly controlled by post transcriptional level (Kohler et al., 1990). It is important to note when designing PCR primer for Listeria sp with iap gene is that, gene showcase sequence variation at species level (Bubert et al., 1992).

\section{$\operatorname{prfA}$ (Positive regulatory factor $\mathrm{A})$}

Presence of $\operatorname{prfA}$ protein has been related with gene expression regulation of several virulence gene expression, such as LIPI-1 gene, inlA. Not only is that, $p r f \mathrm{~A}$ found to be negatively regulated some of the $L$. monocytogenes genes like $c l p \mathrm{C}$ who acts in stress response mediator gene and motility associated genes motA and flaA.

\section{Multiplex PCR targeting virulence marker genes}

In an order to understand pathogenicity and identification of $L$. monocytogenes number of virulent genes such as hly A encoding Listeriolysin O (LLO), invasion associated p60 protein (iap) gene (Kohler et al., 1990), listeriolysin O (hlyA) (Bessesen et al., 1990; Border et al., 1990; Deneer and Boychuk, 1991; Rossenet al., 1991), the iap gene (Jatonet al., 1992 and Kohler et al., 1990) and the plc A gene has been targeted.

In number of food samples, $L$. monocytogenes prf A and hly A gene has been distinctly marked by PCR to detect contamination (Niederhauser et al., 1992, Wernars et al., 1992) and LLO gene (hly A) was successfully used in case of low copy number of bacteria in sample (Wiedmann et al., 1994). Another gene act $\mathrm{A}$ found to be important to detect by PCR especially in L. monocytogenes which many times showcase sequence variability (Moriishi et al., 1998).

For the first time, Lawerence and Gilmour (1994) provided the success of multiplex PCR which is targeting virulence genes of $L$. monocytogenes in a single reaction. Along with that, genes like iap, prf A and hlyA found to be superior in multiplex PCR (Almeida and Almeida, 2000). Wesley et al., (2002) sensibly used multiplex PCR to target 16s rRNA region of $938 \mathrm{bp}$ along with $174 \mathrm{bp}$ of listeriolysin 
(hlyA) of L. monocytogenes. In a set of PCR, this two amplicon acted as successful model to recognize Listeria species and their serotypes successfully.

Multiplex PCR targeting virulence marker genes in bovine environment, Animal clinical cases and milk

For the first time, Cooray et al., (1994) reported the multiplex PCR for $L$. monocytogenesforthree genes prfA, hlyA and plcA successfully and then in 1995 Rasmussenet al., reported that $L$. monocytogenes could be divided into three lineages amplification and subsequent determination of sequence variation of gene $h l y$. Use of RFLP-PCR in the virulence gene hlyAdetection and by also ribotyping found to be successful as reported by Wiedmann et al., (1997).

Multiplex PCR also assists in understanding maximum likelihood phylogenies of several genes especially to classify L. monocytogenes into two deeply separated evolutionary lineages by targeting genes gap, prs,pur $\mathrm{M}$, $r i b \mathrm{C}, \operatorname{sig} \mathrm{B}, \operatorname{act} \mathrm{A}$ and inlA (Nightingale et al., 2005).

Presence of L. monocytogenes in milk, bulk tank, swabs, cheese, feed, water, environment and faeces was confirmed by PCR techniques along with many species such as L. innocua, L. grayi, L. welshimeriand others (Atil et al., 2011). Gelbicova and Karpiskova, (2012) successfully PCR amplified $11.2 \%$ virulent $L$. monocytogenes from environmental samples for several virulence genes $\operatorname{prf\mathrm {A}}, h l y \mathrm{~A}$, actA, plc $\mathrm{A}, p l c \mathrm{~B}$, inl $\mathrm{A}$, in $l \mathrm{~B}$, inl $\mathrm{C}$ and inlJ. Similar to that Meloni et al., (2012) carried out multiplex PCR to target prfA, hlyA, rrn, inlA, $i n l \mathrm{~B}$, act $\mathrm{A}, m p l$, iap, plc $\mathrm{A}$ and $p l c \mathrm{~B}$. Park et al., (2012) identified 35 L. monocytogenes present in animals, foods, environmental samples by carrying out multiplex PCR, and detected six virulence associated genes (inlA, $i n l \mathrm{~B}, p l c \mathrm{~A}, p l c \mathrm{~B}, h l y \mathrm{~A}$ and $\operatorname{cct} \mathrm{A})$ along with 16S rRNA targeting.Usman et al., (2016) identify virulence associated genes such as prfA, inlA,hlyA,actA and iap from milk and milk products in Nigeria.

In India, recently Kaur et al., (2006) targeted L. monocytogenes genes like iap, act $\mathrm{A}$, hlyA, plcA and prfA by multiplex PCR with samples of abortions in human and found to be 5 genes positive in two samples out of 305 tested. Shakuntala et al., (2006) also found to be successful in targeting virulence associated genes prfA, plcA, hly AactA and iap in variable source samples containing $L$. monocytogenes and other species and most of them found to be positive for five virulence associated genes. In a similar attempt number of worker successfully demonstrated this approach can detect L. monocytogenes (Parihar et al., 2007; Rawool et al., 2007; Yadav et al., 2010; Shoukat et al., (2014); Nayak et al., (2015); and Sawant et al., 2016).

\section{Serotyping PCR}

It is noted that no direct link could be made among particular forms of listeriosis and certain serotypes, till the Gellin et al., (1991) put forward some relation between perinatal listeriosis and serovars $1 / 2 b, 3 b$ and $4 b$.

By multiplex PCR, Doumith et al., (2004) first time separated L. monocytogenes serovars from food and patients into distinct groups (1/2a, 1/2b, 1/2c and 4b), Yde and Genicot (2004) studied 48 strains of L. monocytogenes, out of them 26 belonged to serovar $4 \mathrm{~b}$, another 18 to serovar $1 / 2 \mathrm{a}$ and remaining four to serovar $1 / 2 b$.

According to Kessel et al., (2004) tank milk samples from farms in United States found to be positive for L. monocytogenes (6.5\%) of total tested 861 samples and by serotyping, 
five serotypes found to be dominating $1 / 2 \mathrm{a}$, $1 / 2 b, 3 b, 4 b$ and 4c. Esteban et al., (2009) reported that fecal samples of animal herd found to be dominating in serotype $4 \mathrm{~b}(84.2 \%)$ followed by $1 / 2 \mathrm{a}(13.2 \%)$. Gebicova and Karpiskova (2012) confirmed the serotype $1 / 2 \mathrm{a}$ as dominating in $L$. monocytogenes recovered from wild, farm environment and vegetation. Centinkaya et al., (2014) when tested raw milk, dairy producs and food products like chicken meat, sea food and raw vegetables presence of $L$. monocytogenes was confirmed with dominating serotype 1/2a, $1 / 2 b, 1 / 2 c$ and $4 b$ in descending order when serotyped by multiplex PCR.

Arora et al., (2009) reported by multiplex PCR assay that milk and milk product isolated L. monocytogenes, found to be dominating $(72 \%)$ with serovar group 4b, 4d, 4e 22\% (4/18) to serovar group $1 / 2 b, 3 b$ and $5.5 \%$ (1/18) to serovar group 1/2a, 3a. Similar report publish by Sonegaonkar (2009)recorded that food of animal origin $L$. monocytogenes majorly belongs to serovar $4 \mathrm{~b}$ group. In several samples, animal origin, raw poultry meat found to be mainly positive with serovar $4 b$.

Mastitic milk samples also found to be positive for $L$. monocytogenes and when sterotyped by multiplex PCR, all of them serotyped for 4b (Yadav et al., 2010). Dixit (2013) tested 150 clinical samples and successfully detected Listeria species with majority of them serotyping positive for $4 \mathrm{~b}$. Raorane et al., (2014) when tested 215 samples clinical $(n=182)$ and farm environment $(n=33)$ most of them found to contain L. monocytogenes dominating with serotype $4 \mathrm{~b}$ and 1/2b. Negii et al., (2015) when tested food, human and animal clinical cases, three serotypes found to be dominating in L. monocytogenes which are $4 \mathrm{~b}, 4 \mathrm{~d}, 4 \mathrm{e}$ followed by $1 / 2 \mathrm{a}, 3 \mathrm{a}$ and last by $1 / 2 \mathrm{~b}$ and $3 \mathrm{~b}$ serogroups.

\section{Pulse field gel electrophoresis}

In a diagnostic epidemiological approach detection of L. monocytogenes is possible by number of molecular techniques like Random Amplification of polymorphic DNA (RAPD), Microarray analysis, Amplified Intergenic Locus Polymorphism (AILP), Multilocus Enzyme Electrophoresis (OIE, 2008). Along with that, Genomic macro restriction endonuclease digestion followed by pulse field gel electrophoresis is becoming popular assay to detect number of food pathogens in several applications as suggested by Graves and Swaminathan (2001); Fugett et al., (2007). This technique certainly making its presence owing to higher discriminatory power, accuracy and proven to be useful in surveillance and control of listeriosis (Graves and Swaminathan, 2001; Jeffers et al., 2001).

As it is known L. monocytogenes represents number of clonal group which can have different pathogenic potential (Jeffer et al., 2001). In requirement, power PFGE certainly been useful to study epidemiological aspect of L. monocytogenes (He et al., 2008; Felix et al., 2012; Fox et al., 2012). It has also been successful to track the L. monocytogenes contamination in food source (Fugettet al., 2007; Conter, 2008). Zhang et al., (2007) performed the PFGE analysis of $L$. monocytogenes isolated from retail ready to eat meat fresh produce and raw chicken along with techniques like PCR.

Wojciech et al., (2004) put forward the success of PFGE with detection of $L$. monocytogenes in food stuff and animal clinical cases. They recorded that ERIC-PCR and PFGE has different genotypes of $L$. monocytogenes from food derived samples than the infected animal samples. Vela et al., (2001) studied L. monocytogenes with PFGE when they were isolated from sheep, cattle, 
feed stuffs and from human. They recorded 84 animals, 51 human and total 18 food strains showcasing 31, 29 and 7 different pulsotype, respectively, which has indicated a great genetic diversity among Spanish $L$. monocytogenes.

Borucki et al., (2004) demonstrated that PFGE could be useful in comparative studies of $L$. monocytogenes originating from different sources like human and animals dairy associated strains such as milk, environment and bovine they recorded that $23 \%$ of human sporadic strain had PFGE pattern common to that of farm isolates which makes PFGE important diagnostic or surveillance tool. Borucki et al., (2005) put forward the use of PFGE in testing transmission of listeriosis from one farm to another and also reported that fecal samples found to be positive for most of samples of cow and serotype 1/2a reported most of the time. Okwumabua et al., (2005) put forward that isolated $L$. monocytogenes from animal clinical samples of mastitis, abortion, meningitis and from food could be analyzed by PFGE. They reported that a caprine, two bovine and an ovine brain isolate resulted in identical PFGE banding pattern which gives a theory that available strains of L. monocytogenes are not host specific. Further by dendrogram of PFGE pattern isolates clustered majorly with respect to serotype.

Negi et al., (2015) profiled PFGE of human and animal clinical samples collected from different geographical locations for $L$. monocytogenes. They recorded 17 pulsotypes among 36 L. monocytogenes recovered from animal, human and clinical cases and foods with 6 major clusters having similar finger print profile and within them 11 unique cluster finger print profile was recorded. Hence, they recommended PFGE analysis in food of animal origin for infection source detection. According to Barbudhhe et al., (2016) majority of the serotype $4 \mathrm{~b}$ strains from India were clonal, and altogether $68.80 \%$ serotype $4 \mathrm{~b}$ strains exhibited identical pulsotype for the samples isolated from animals, humans, food and environment.

\section{Biofilm production of $L$. monocytogenes}

Biofilm production is considered as one of the major weapons of pathogen defense as evidenced in following reports. Norwood and Gilmour, (2001) reported that biofilms are surface associated, sessile bacterial communities. This film confers protection against physical and chemical stresses. In human many chronic illness are reported with biofilm formation and hence major focus has been put forward for the genes involved in such activity (Parsek and Singh, 2003). Vatanyoopaisarnet al., (2000) firstly related flagella of L. monocytogenes on initial attachment to stainless steel. They recorded this mechanism assist in early stage of attachment. Lemon et al., (2007) also reported that flagellum mediated motility of $L$. monocytogenes is responsible for the both initial surface attachment and thereafter biofilm formation.

As per reports, it is important to detect ability to form biofilm and Djordjevic et al., (2002) designed a polyvinyl chloride (PVC) microfilter plate assay which can test biofilm formation by $L$. monocytogenes. They successfully demonstrated quantitative biofilm formation by epifluorescence microscopy. Borucki et al., (2003) further related $L$. monocytogenes in relation to biofilm formation, phylogenic division and persistence in the environment. They have observed that serotypes $1 / 2 \mathrm{a}$ and $1 / 2 \mathrm{c}$ showcase increased biofilm formation and persistent strains majorly showing increased biofilm formation. Stepanovic et al., (2004) estimated biofilm formation on plastic with $L$. monocytogenes and observed that nutrient content of the 
medium governs the quantity of biofilm production. Di Bonaventura et al., (2008) related L. monocytogenes biofilm with material and temperature. They recorded that biofilm level is on higher sider in glass material with incubation at 4,12 and $22^{\circ} \mathrm{C}$ as compared to polystyrene and stainless steel. Similarly when culture allowed to grow at $37^{\circ} \mathrm{C}$, L. monocytogenes produced higher level of biofilm on glass and stainless steel, as compared to polystyrene material.

Dubravk et al., (2007) put up a relation between temperature and medium used for biofilm production. They tested $L$. monocytogenes strains growing on 1/20 diluted tryptophan- soy broth with yeast extract (TSB-YE), Brain-heart infusion (BHI) and tryptophan- soy broth with yeast extract at temperature $4{ }^{\circ} \mathrm{C}, 25{ }^{\circ} \mathrm{C}$ and $37{ }^{\circ} \mathrm{C}$. As per report no significant change occurs with biofilm production even by changing medium and temperature which highlighted independence of this medium or temperature for biofilm formation. Harvey et al., (2007) used microtiter plate assay to quantify biofilm production of 138 strains of L. monocytogenes isolated from environment animal food and clinical were classified $(92.0 \%)$ as weak, $(6.5 \%)$ as moderate and $(1.5 \%)$ as strong biofilm farmers.

Looking at these features, microbial biofilms put up serious questions in clinical and industrial settings and majorly to food processing environments which may lead to food contamination and spoilage and that certainly will assist in transmission of pathogens (VanHoudt and Michielis, 2010).

In a view to monitor the food contamination by biofilm, Latorre et al., (2010) demonstrated the use of scanning electron microscopy (SEM) by collecting small pieces like milk meter and rubber liners of tankers and exposing it in SEM. This approach is successful in milk industry for regular monitoring (Latorre et al., 2010).

Borges et al., (2011) simulated vaginal fluid maintained at $\mathrm{pH}$ 4.2, 5.5, and 6.5 and observed that L. monocytogenes can produce biofilm but highest was produced in nutrient rich medium. Slama et al., (2012) related activity of biofilm formed by $L$. monocytogenes when isolates were given before and after cold stress $\left(-20^{\circ} \mathrm{C}\right)$. They observed that cold stressed strains were more adhesive to material like polyethylene; polyvinyl chloride, glass and even stainless steel. Barbosa et al., (2013) mentioned that clinical isolates of $L$. monocytogenes are strong biofilm producer than food isolates when tested in laboratory condition at $37^{\circ} \mathrm{C}$ for 24 hours using polystyrene tissue culture plates.

With microtiter assay, L. monocytogenes isolated from minced meat/chicken showed stronger biofilm producing ability as compared to isolates from sausages when tested in laboratory conditions for $24 \mathrm{~h}$ at $20^{\circ} \mathrm{C}$ on polystyrene surface (Fouladynezhadet al., 2013).

Sonegaonkar (2009) confirmed the $L$. monocytogenes isolated from human, raw poultry, fish and milk samples are majorly biofilm producers. Gurjer (2010) also confirmed by multiplex PCR and by CRA method that virulence and biofilm production is positive in poultry isolates, human isolates and milk isolates.

Doijad et al., (2015) related serotypes with biofilm formation and with micro titer plate assay. Majority of clinical and food source $L$. monocytogenes are weak, biofilm producer and hence no firm correlation was recorded with serotype and respective biofilm formation capability. 
Biofilm associated genes (lux $\mathrm{S}$ and fla $\mathrm{A}$ ) of L. monocytogenes

Inactivation of flagellar gene fla $\mathrm{A}$ has been related with impairment of biofilm formation and initial attachment in $L$. monocytogenes (Kumar and Anand, 1998). In response Gray and Kroll (1995) firstly reported the standardized PCR method which can distinctly amplify internal fragment of fla A gene of genus Listeria which allows specific genus discrimination between other Gram-positive and Gram-negative bacteria and other Listeria species.

By using PCR technique, Stranchan and Gray (1995) amplified a 200 mer fragment of the flaA gene by incorporating biotin and fluorescein amadite (FAM) - labelled primers as one of the success to diagnose $L$. monocytogenes.

Another gene luxS has been found to be involved in repression of components that take part in attachment of biofilm formation and this is confirmed when $L$. monocytogenesluxSstrain produce denser biofilm than normal to a glass surface as recorded by Sela (2006). Many studies confirm that lux $\mathrm{S}$ gene is present virulent $L$. monocytogenes along with flaA gene (Gurjer, 2010; Kumar et al., 2009).

\section{Disinfectant resistance of $L$. monocytogenes}

Presence of L. monocytogenes in animal farm environment and animal clinics with disinfectant resistance is not so well studied. It is also not so clear about the exact mechanism of resistance present in L. monocytogenes.

To tackle the power of sanitizers, probably $L$. monocytogenes uses efflux pump which can transport a range of structurally dissimilar compounds. As per Toet al., (2002) very little is known about regulation of these transporters at a level of gene expression in $L$. monocytogenes.
In number of resistance assay of disinfectant successor $L$. monocytogenes does found to be winning the race. According to Best et al., (1990) out of 14 disinfectants, only 3 disinfectants (providone-iodine, chlorhexidine, gluconate and glutaraldehyde) were found to be effective against $L$. monocytogenes in a mass screening. Aase et al.,(2000) recorded that out of 200 L. monocytogenes, only $10 \%$ were reported resistant to benzalkonium chloride (BC). This resistant has been linked with apmf- driven efflux pump.

\section{Efflux pump and disinfectant resistance gene}

Mata et al., (2000) probably for the first time reported chromosomal gene $(m d r \mathrm{~L})$ in $L$. monocytogenes L028, resembling with multidrug efflux transporters of the major facilitator super family. In the same year, Mereghetti, (2000) detected $m d r \mathrm{~L}$ gene in $L$. monocytogenes which codes multidrug efflux pump and another gene orf A which act as transcriptional repressor of $m d r \mathrm{~L}$. Thereafter, Romanova et al., (2006) further confirmed $m d r \mathrm{~L}$ gene with sanitizer and antibiotic resistance as it encodes efflux pump which has been related to quaternary ammonium compounds. These genes are encoded by both chromosomal as well as plasmid. This $m d r \mathrm{~L}$ efflux pump has been confirmed by the Mullapudiet al., (2008) also which can act in extrusion of toxic ions such as $\mathrm{BC}$, ethidium bromide and heavy metals.

Another gene Sig B, encoding major transcriptional regulator of stress response gene found to be associated with resistance to disinfectant via continuous formation of biofilm as reported by Van der veen and Abee (2010). According to Rakic-Martinez et al., (2011) efflux pump once gets expose to BC or certain antibiotics or heavy metals, it gets sensitize and starts removing the ions that sensed as a toxic. 


\section{Real time PCR assay (q PCR)}

It is always been suggested to follow traditional microbial methods to detect Listeria spp. which involves pre enrichment followed by isolation on solid/liquid medium and confirmation by biochemical methods (Jasson et al., 2010, Mandal et al., 2011). However, as the technology advances have been experienced towards more specific and sensitive PCR technology to identify organisms at molecular level.

Number of researchers successfully demonstrated the use of real PCR assay to detect $L$. monocytogenes in number of samples. They have also successfully discriminated the close Listeria species by targeting hlyA, iap gene for L. monocytogenes (Lazaro et al., 2004; Guilbaud, 2005). Burbano, (2006) developed a PCR technique which can detect as low as $10 \mathrm{CFU} / \mathrm{ml}$ of $L$. monocytogenes in raw milk DNA with the amplicon of $938 \mathrm{bp}$ and $750 \mathrm{bp}$ and it certainly remained genes and species specific. Rossmanith et al., (2006) utilizes combine/real time PCR method for the detection of $L$. monocytogenes by targeting universal marker gene prfA for L. monocytogenes. They detected as low as $7.5 \mathrm{CFU} / 25 \mathrm{ml}$ in raw milk, minimum 1CFU/15g of cheese and its relative accuracy stands up to $96 \%$ with relative specificity $100 \%$ and relative sensitivity, $76.9 \%$. In another approach, Yanget al., (2007) adapted a method of combining nanoparticles based immunomagnetic separation (IMS) with the use of real time PCR to detect L. monocytogenes. The method successfully detected milk sample with $L$. monocytogenes as low as $\geq 10^{2} \mathrm{CFU} / 0.5 \mathrm{ml}$ and CT value found to be recording 1.5 to 7 times higher value than those derived from plate count suggested its success.

O'Grady (2008) detected the ssrA gene by using real time PCR by amplifing its $162 \mathrm{bp}$ fragment available in L. monocytogenes. The success lies in the fact that only 1-5 CFU of $L$. monocytogenes per $25 \mathrm{gram} / \mathrm{ml}$ of food sample in 30 hour could be detected especially in soft cheese, meat, milk, vegetables and fish. Omiccioli et al., (2009) developed the multiple PCR based platform which can detect along with $L$. monocytogenes, pathogens like Salmonella sp, E. coli. This developed multiplex real time PCR utilizes either dual labelled probes (m RT-PCR) or melting curve analysis (m HRH) with the detection limit of 1 CFU for each pathogen in a total of five with $25 \mathrm{ml}$ aliquots of raw milk.

Vanegas et al., (2009) successfully used real time PCR to detect $L$. monocytogenes in raw milk by targeting 149 bp fragment of metalloprotease $(\mathrm{mpl})$. They reported the success of real time as out of 81 samples, real time PCR confirmed 21 positive while, only 13 reported positive by conventional method.

In number of reports, success of real time has been highlighted use of qPCR found to be useful in food and clinical sample was demonstrated by Alessandria et al., 2010; Piednoir et al., 2013; Wang et al., 2014. Real time PCR method for detection of $L$. monocytogenes in chilled pork was successfully demonstrated which need no prior enrichment. Amagliani et al., (2012) showcase the success of multiplex real time PCR assay as compared to culture based approach to detect L. monocytogenes infarm quality assurance program. Claytonet al., (2011) developed real time PCR assay which can detect LLS-positive L. monocytogenes by targeting $l l s \mathrm{X}$ gene. The test is highly specific with detection limit of 1 CFU of an LLSpositive strain $25 \mathrm{~g} / \mathrm{ml}$ of spiked foods in less than $30 \mathrm{~h}$. when this assay was coupled with culture enrichment. Wang et al., (2011)and Liu et al., (2012) used real time PCR to detect L. monocytogenes in simulated milk samples by targeting hlyA gene involving pair of 
primers and Taq-Man probe for qualitative detection. The test is highly specific to $L$. monocytogenes with sensitivity of assay lies with 9 copies per PCR reaction. Amagliani et al., (2012) confirmed the higher sensitivity of real time PCR as compared to culture approach especially to detect $L$. monocytogenes, E. coli and Salmonella sp in bulk tank milk, in-line milk filters, manure and faeces. Success of real time PCR once again evidenced, when Dadkhah et al., (2012) demonstrated real time PCR superity compared to plating method. Where plate count can detect minimum 1.58 to $1.58 \times 10^{7}$ $\mathrm{CFU} / \mathrm{ml}$ in milk sample and by PCR it can detect as low as four copies of iap-gene which delivers the sensitivity and specificity of real time PCR. Dehkardi et al., (2013) demonstrated series of success in detection of L. monocytogenes in milk, faeces, vaginal swab and urine samples when tested for conventional cultural method, conventional PCR and light cycler real time PCR. They demonstrated $8.53 \%$ positive results for cultural, 9.19\% for conventional PCR and $11.96 \%$ positive results with same samples for real time PCR which put forward the defined success of real time PCR.
Singh et al., (2011) utilized the power of duplex real time PCR assay which could simultaneously detect L. monocytogenes by targeting hlygene, respectively. The protocol could detect as low as 3 and 4 CFU per ml of L. monocytogenes and Salmonella spwithout any pre-encrichment required. However, with pre-enrichment this limit improves upto 1 CFU per ml of pathogens.

Overall it has been evidenced that by targeting the virulence associated genes in real time PCR fast, accurate, sensitive and specific detection of L. monocytogenes is possible and may be extended for diagnosis of $L$. monocytogenes in milk and clinical samples.

The study of incidence of Listeria monocytogenes in bovines and their environment provide information about contamination status of milk, animal clinical cases and bovine environment. The presence of $L$. monocytogenes in bovines and their environment could be a potential risk for animals and human beings. Further strategies to reduce the occurance of the organism in bovine environment are required to overcome the contamination.

Table.1 Serovar grouping of the isolates

\begin{tabular}{|c|c|c|c|c|c|}
\hline $\begin{array}{l}\text { Sr. } \\
\text { No }\end{array}$ & Serogroup & Milk & $\begin{array}{l}\text { Animal Clinical } \\
\text { Cases }\end{array}$ & Environment & $\begin{array}{c}\text { Tota } \\
1\end{array}$ \\
\hline 1 & $4 \mathrm{~b} .4 \mathrm{~d}, 4 \mathrm{e}$ & 2(M8,M14) & ---- & 1(E3) & 3 \\
\hline 2 & $\begin{array}{c}1 / 2 \mathrm{a}, 1 / 2 \mathrm{c}, 3 \\
\mathrm{a}, 3 \mathrm{c}\end{array}$ & ---- & ----- & 1(E16) & 1 \\
\hline 3 & $\begin{array}{c}1 / 2 b, 3 b, 4 b \\
4 d, 4 \mathrm{e}\end{array}$ & $\begin{array}{c}\text { 10(M1,M2,M5,M } \\
\text { 6,M7,M9,M11,M } \\
\text { 13,M16,M17 }\end{array}$ & $\begin{array}{c}14(\mathrm{ACC}- \\
2,4,5,6,8,9,10,11 \\
12,13,14,15,16, \\
17)\end{array}$ & $\begin{array}{c}\text { 10(E5,E9,E11,E1 } \\
\text { 2,E13,E14,E15,E } \\
\text { 18,E24,E25) }\end{array}$ & 34 \\
\hline & Total & 12 & 14 & 12 & 38 \\
\hline
\end{tabular}


Plate.1 Agarose gel showing Multiplex PCR serotyping for determination of the serovargroups of isolates obtained from bovine environment, animal clinical cases and milk . Lane1: isolates E16 L. monocytogenes serogroup1/2a ;Lane 2: E coli- Negative Control Lane3: 100 bp DNA ladder; Lane 4 : isolates M-5 L. monocytogenes serogroup $1 / 2 \mathrm{~b}$ and $4 \mathrm{~b}$; Lane 5: isolatesACC-3 L. monocytogenes serogroup $1 / 2$ band $4 \mathrm{~b}$; Lane6 : isolate-E-3 L. monocytogenes serogroup 4b ; Lane 7: L.monocytogenesEGDe as a standard for serotypes 1/2a; Lane8 : isolate M-14 L. monocytogenes serogroup 4b.

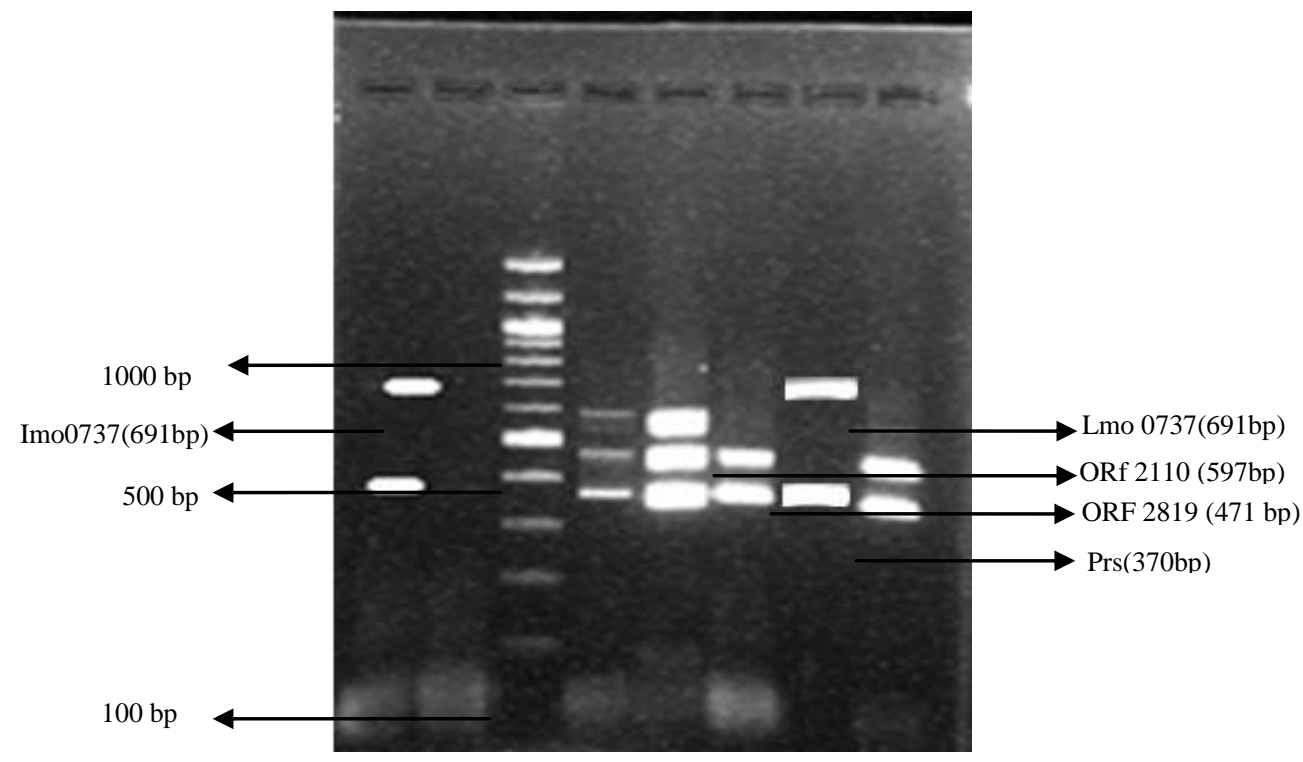

Plate.2 Dendrogram derived from PFGE Profile of AscI and ApaImacroristriction showing restriction pattern similarityamong 38 L. moncytogenesbovine environment, animal clinical and milk isolates with strain EGDe.
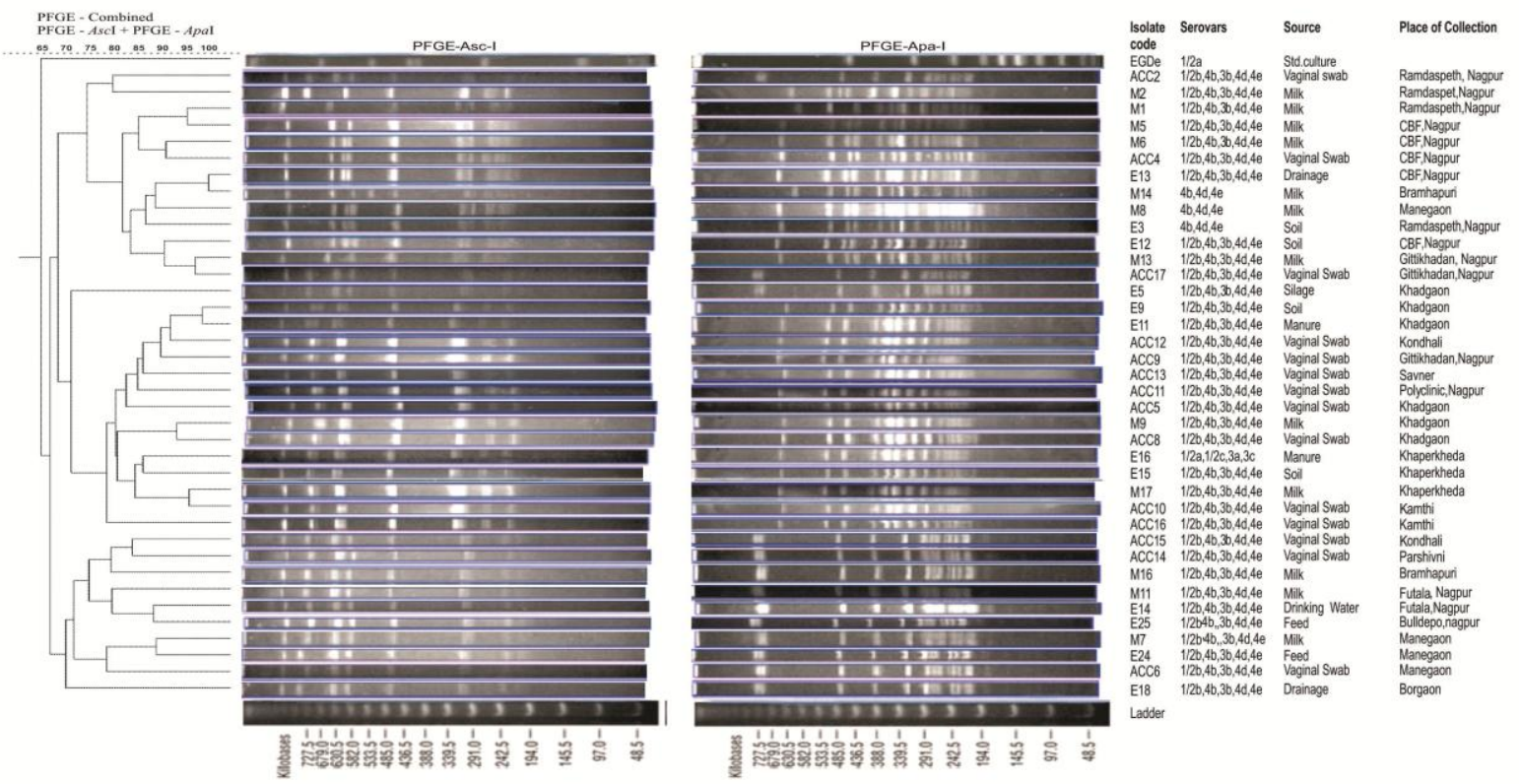


\section{References}

Aase, B., G. Sundheim., S.Langsrud., L.M. Rørvik (2000) Occurrence of and a possible mechanism for resistance to a quaternary ammonium compound in Listeria monocytogenes. Int.J.Food Microbiol. 62: 57-63. doi: 10.1016/S0168-1605(00)00357-3. PubMed: 11139022.

Alessandria, V., K. Rantsiou., P. Dolci and L. Cocolin (2010). Molecular methods to assess Listeria monocytogenes route of contamination in a dairy processing plant. Int. J. Food Microbiol. 141 (1): $156-62$.

Allerberger, A and M. Wagner (2010) Listeriosis: a resurgent foodborne infection.Clin.Microbiol.Infec. 16: 1623.

Almeida, P. F. and R. C. C. Almeida (2000).A PCR protocol using inl gene as a target for specific detection of Listeria monocytogenes.Food Control.11 : 97101.doi: 10.1016/S0956-7135(99)0006 7-5.

Amagliani, G., A. Petruzzelli, E. Omiccioli, F. Tonucci, M. Magnani and G. Brandi. (2012). Microbiological Surveillanc of bovine raw milk farm through multiplex real time PCR. Food borne Pathogen.Dis. 9(5): 406-411.

Atil, E., H. Ertas., and G. Ozbey (2011) Isolation and molecular characterization of Listeria spp. from animals, food and environmental samples, Vety. Medicina (8): 386-394.

Aurora R., A.Prakash and S.Prakash (2009) Genotypic Characterization of Listeria monocytogenes isolated from milk and ready to eat indigenous milk products. Food Control. 20: 835-839.

Barbosa, J., S. Borges., R.Camilo., R. Magalhães., V. Ferreira., I. Santos., J. Silva., G.Almeida., and P.Teixeira (2013) Biofilm Formation among
Clinical and Food Isolates of Listeria monocytogenes. Int.J. Microbiol.1-6.

Barbuddhe S., S.V.S. Malik., K.N. Bhilegaonkar., P.Kumar and L..K. Gupat (2000) Isolation of Listeria monocytogenes and anti-listeriolysin $\mathrm{O}$ detection in sheep and goats. Small. Rumin. Res. 38(2): 151-155.

Barbuddhe, S. B., S.P.Chaudhari and S.V.S. Malik (2002). The occurrence of pathogenic Listeria monocytogenes and antibodies against listeriolysin-O in buffaloes.Zoonosis and Public Health. 49(4): 181-184.

Barbuddhe, S., T. Hain and T.Chakraborty (2008). The Genus Listeria. In E. Goldman and L. Green (Eds.), Practical Handbook of Microbiology (Ed. I., pp. 533-562). Boca Raton: CRC Press.

Barbuddhe, S.B., S.P. Doijad. A. Goesmann, R. Hilker, K.V. Poharkar, D. B Rawool, N.V. Kurkure, D. R. Kalorey, S. V. S Malik, I. Shakuntala, S. Chaudhari, V. Waskar, Dilecta D'Costa, R. Kolhe, R. Arora, A. Roy, A. Raorane, S Kale, A. Pathak, M. Negi, S.Kaur, R. Waghmare, S. Warke, S. Shoukat, B. Harish, A. Poojary, M. Chakodabail, K. Nagappa, S. Das, R. Zende, S. Garg, S. Bhosle, S. Radriguez, A. Paturkar, Mo. Fritzenwanker, H. Ghosh, T. Hain and T. Chakraborty. (2016). Presence of a widely disseminated Listeria monocytogensserotype $4 \mathrm{~b}$ clone in India. Emerg.Microbes. Infect. 5(6): e55.10.1038/emi.55.

Barkallah, M.Y., A.B. Gharbi., A.B. Hassena and Slima A.B. (2014) Survey of infectious etiologies of bovine abortion during mid to late gestation in dairy herds. PLoS One 9(3): e91549.

Ben Embarek P.K. (1994) Presence, detection and growth of Listeria monocytogenes in seafoods: a review. Int. J. Food 
Microbiol. 23(1): 17-34.

Bessesen, M. T., Q. Luo., H. A. Rotbart., M. J. Blaser and R. T. Ellison (1990) Detection of Listeria monocytogenes by using the polymerase chain reaction. Appl. Environ. Microbiol.56: 2930-2932.

Best, M., M. E. Kennedy and F. Coates (1990). Efficacy of a variety of disinfectants against Listeria spp. Appl. Environ. Microbiol. 56(2): 37780.

Bhilegaonkar, K. N., S.B. Kulshreshtha., K.N.Kapoor., A. Kumar., R.K. Agarwal and B.R. Singh (1997) Isolation of Listeria monocytogenes from milk. J. Food Sci. Tech. 34: 248250.

Bhujwala, R.A., R.K.Chandra and V. Hingorani (1974) Listeria meningitis in Delhi (A pilot study). Indian J. Med. Res. 62: 1333.

Border, P.M.,J.J. Howard.,G.S. Plastow and Siggens, K.W. (1990) Detection of Listeria species and Listeria monocytogenes using polymerase chain reaction.11(3): 158-162.

Borges, S.F., J.G. Silva and P.C. Teixeira (2011) Survival and biofilm formation of Listeria monocytogenes in simulated vaginal fluid: influence of $\mathrm{pH}$ and strain origin. FEMS Immunol Med Microbiol. 62(3): 315-20. doi: 10.1111/j.1574-695X.2011.00815.x. Epub.

Borucki, M.K. and D.R. Call (2003) Listeria monocytogenes serotype identification by PCR. J Clin. Microbiol. 41 : 55375540.

Borucki, M.K., J. Reynolds., C.C. Gay., K.L. Mcelwain., S.H. Kim., P. Donald., D.P. Knowles, and J. Hu (2004) Dairy Farm Reservoir of Listeria monocytogenes Sporadicand Epidemic Strains. J. Food Prot. 67(11): 24962499.
Borucki, M.K., C.C. Gay., J.Reynolds.K.L. McElwain., S.H. Kim., R.C. Douglas and P.K. Donald (2005). Genetic Diversity of Listeria monocytogenes Strains from a High-Prevalence Dairy Farm. Appl.and Environ. Microbiol. 71(10): 5893-5899.

Bubert, A., H., M. Kestler, R. Gotz., Bockmann and W. Goebel (1997) The Listeria monocytogenes iap gene as an indicator gene for the study of prfAdependent regulation. Mol. Gen. Genet. 256: 54-62.

Bubert, A., S. Kohler and W. Goebel (1992) The homologous and heterologous regions within the iap gene allows genus and species specific identification of Listeriaspp. by Polymerase chain reaction. Appl. Environ Microbiol. 58(8): 2625-2632.

Burbano, E.(2006) Rapid DNA extraction and PCR Validation for direct detection of Listeria monocytogenes in raw milk. Revista MVZ Cardoba. 11: 715-724.

CarareCarp, C. (2006). Cercetari bacteriologice privind Listeria monocytogenes is implicatile sale epidemiologice, Ph.D. Thesis, university of Agricultural Sciences and veterinary Medicine, lasi.

Centinkaya, F. T.E. Mus., A. Yibar., N.Guclu., H. Tavsanli and R. Cibik (2014). Prevalence serotype, identification by multiplex polymerase chain reaction and antimicrobial resistance patterns of Listeria monocytogenes isolated from retail foods. Indian Vet. J. 81: 1313 1316.

Chopra, S., V., S. Sharma., S. Shukla and A. Nayak (2012) Antibiogram of Listeria spp. isolated from reproductive disorders and livestock products of ruminants. J. Ani. Res. 2(2):87-190.

Clayton, E.M., C. Hilly., P.D. Cotter and P. Ross (2011) Real-Time PCR assay to differentiate Listeriolysin $S$ - positive 
and -Negative Strains of Listeria monocytogenes. Appl. Environ. Microbiol. 77(1): 163-171.

Connor, L.O., M. O' Leary., N. Leonard., M. Godinho., C O’ Reilly, J.E. Gan., R.O. Mahony (2010) The Characterization of Listeria spp. isolated from food products and the food processing environment. Lett. Appl. Microbiol. 51(5): 490-498.

Conter M. (2008) Sources and tracking of Listeria monocytogenes in a cold smoked processing plant. Annali della Facoltà di Medicina Veterinaria di Parma, XXVIII.

Cooray, K. J., T. Nishibori., H. Xiong., T. Matsuyama., M. Fujita and M. Mitsuyama (1994) Detection of multiple virulence-associated genes of Listeria monocytogenes by PCR in artificially contaminated milk samples. Appl. Environ. Microbiol. 60: 30233026.

Dalton, C.B., C.C. Austin., J. Sobel., P.S. Hayes., W.F. Bibb., L.M. Graves., B. Swaminathan.,M.E. Proctor and P.M.Griffin (1997) An outbreak of gastroenteritis and fever due to Listeria monocytogenes in milk. N.Engl. J. Med. 9: 336(2): 100-5.

Deb, R.,A. Kumar., S. Chakraborty., A.K. Verma., R. Tiwari., K. Dhama, U.Singh and S. Kumar (2013). Trends in diagnosis and control of bovine mastitis: A review. Pak. J. Biol. Sci.16 (23): 1653-1661.

Deneer, H.G. and I Boychuk (1991).Speciesspecific detection of Listeria monocytogenes by DNA amplification. Appl. Environ.Microbiol. 57(2): 606609.

Dhama K., A.K.Verma., S. Rajagunalan., A. Kumar., R. Tiwari., S. Chakraborty and R. Kumar (2013). Listeria monocytogenes infection in poultry and its public health importance with special reference to food borne zoonoses, Pak. J. Biol. Sci.16(7): 301308.

Dhanashree, D., S.K. Otta., I. Karunasagar., W.Goebel and I.Karunasagar (2003) Incidence of Listeria spp. in clinical and food samples in Mangalore, India.Food Microbiol. 20: 447-453.

Di Bonaventura, G., R. Piccolomini., D. Paludi, V. D'Orio., A. Vergara, M. Conter and Ianieri, A. (2008). Influence of temperature on biofilm formation by Listeria monocytogenes on various food-contact surfaces: relationship with motility and cell surface hydrophobicity. J. App. Microbiol. 104(6): 1552-61.

Dixit, M. (2013) Molecular Characterization of Listeria monocytogenes from reproductive disorders in ruminants. M.V.Sc. Thesis submitted to Maharashtra Animal \& Fishery Sciences University, Nagpur.

Djordjevic, D., M. Wiedmann, and L. A. McLand sborough (2002) Microtiterplate assay for assessment of Listeria monocytogenes biofilm formation. Appl.Environ. Microbiol. 68: 2950-2958.

Doijad S., S.B. Barbuddhe., S. Garg., S. Kalekar., J. Rodrigues., D. Decosta.,S. Bhosale and T. Chakraborty (2011) Incidence and genetic variability of Listeria species from three milk processing plants. Food Contl. 22(12): $1900-1904$.

Doijad, S.P., S.B. Barbuddhe., S. Garg., K.V. Phoharkar., D.R. Kalorey., N.V. Kurkure., D.B. Rawool and T. Charaborty (2015) Biofilm-Forming Abilities of Listeria monocytogenes Serotypes Isolated from Different Sources. PLOS ONE DOI:10.1371/journal.pone.0137046.

Donnelly, C.W. (2002) Detection and isolation of Listeria monocytogenes from food 
samples implications of sub lethal injury. Int. J. of AOAC. 85: 495-500.

Doumith, M.C. Buchrieser., P. Glaser., C. Jacquet and P. Martin (2004) Differentiation of the major Listeria monocytogenes serovars by multiplex PCR. J. Clin. Microbiol. 42: 38193822.

Dubravka, M., A[ANIN RU@ICA, MI[I] D VIDI] Branka and R. Ratajac (2007) Investigation of biofilm formation in vitro ability of Listeria monocytogene strains isolated from animals. Acta Veterinaria (Beograd), 57 (5-6): 429440.

Esteban J.I., B. Oporto., G. Aduriz.,R.A. Juste and A. Hurtado (2009) Faecal shedding and strain diversity of Listeria monocytogenes in healthy ruminants and swine in Northern Spain. BMC Vety. Res. 5: 2.

Félix, B., T. Dao., J. Grout.,B. Lombard., A. Asséré., A. Brisabois and S. Roussel (2012). Pulsed-field gel electrophoresis, conventional, and molecular serotyping of Listeria monocytogenes from food proficiency testing trials toward an harmonization of subtyping at European level. Foodborne Patho. Dis. 9(8): 719-26.

Fenlon, D.R. (1986b) Growth of naturally occurring Listeria spp. In silage: a comparative study of laboratory and farm ensiled grass. Grass Forage Sci 41:375-378.

Fouladynezhad, N., L. Afsah-Hejri., Y. Rukayadi, S, M. Abdulkarim, M. N. Marian and R. Son (2013). Assessing biofilm formation by Listeria monocytogenes. Int. Food Res. 20(2): 987-990.

Fox, E., N. DeLappe., P.Garvey, P. McKeown., M.Cormican., N. Leonard and K. Jordan\ (2012) PFGE analysis of Listeria monocytogenes isolates of clinical, animal, food and environmental origin from Ireland. J. of Medi. Microbiol. 61(4): 540-547.

Fugett, E.B., D.S. Bopp., N.B. Dumas., J. Corby and M. Wiedmann (2007) Pulsed-Field Gel Electrophoresis (PFGE) Analysis of Temporally Matched Listeria monocytogenes isolates from Human Clinical Cases, Foods, Ruminant Farms, and Urban and Natural Environments Reveals Source-Associated as Well as Widely Distributed PFGE Types. J. Clin. Microbiol 45(3): 865-873.

Gelbicova, T. and R. Karpiskova (2012) Outdoor environment as a source of Listeria monocytogenes in food chain. Czech J. Food Sci. 30(1) : 83-88.

Gellin, B. G., C. V.Broome., W. F. Broome., W. F.Bibb., R. E.Weaver., S.Gaventa., L. Mascola and the Listeriosis study group (1991)The epidemiology of listeriosis in the United States - 1986. Am. J. Epidemiol. 133: 392-401.

Gilbert, R.J., K.L. Miller andD. Roberts (1989) Listeria monocytogenes and chilled foods. 18:1(8634): 383-4.

Goulet, V., J. Rocourt., I. Rebiere., C. Jacquet., C. Moyse., P. Dehaumont., G. Salvat and P. Veit (1998) Listeriosis outbreak associated with the consumption of 'rillettes' in France in 1993. J. Infect. Dis. 177: 155-160.

Goulet, V., C. Hedberg, A. Le Monnier A and De Valk H (2008) Increasing incidence of listeriosis in France and other European countries. Emerging Infect. Dis. 14734-14740.

Graves, L. and B. Swaminathan (2001) PulseNet standardized protocol for subtyping Listeria monocytogenes by macrorestriction and pulsed-field gelelectrophoresis. Int. J.Food Microbiol. 65(1-2): 55-62.

Gray, D.I. and R.G. Kroll. (1995). Polymerase chain reaction amplification of the flaA gene for the rapid identification of 
Listeria spp. Lett. Appl. Microbiol. 20 (1): 65-8.

Guilbaud, M. (.2005) Quantitative detection of Listeria monocytogenes in biofilms by real-time PCR. Appl. Environ. Microbiol.71:2190-2194.

Gunjal, P.S. (2006) Genotype characterization of Listeria spp. from raw poultry meat employing polymerase chain reaction. M.V.Sc. Thesis submitted to Maharashtra Animal and Fishery Sciences University, Nagpur.

Gupta, V., V. Gautam., N. Mehta., I. Kumari and R.M. Joshi (2003) Listeriosis in second trimester of pregnancy: Case report from India. J. Infect. Dis. 56: 60-61.

Gurjar, P (2010) Studies on Biofilm formation and associated genes in Listeria monocytogenes" submitted to Rashtrasant Tukadoji Maharaj Nagpur University, Nagpur, in partial fulfillment of the requirement for the award of degree of Master of Science in Biotechnology,

Harvey, J., K.P. Keenan and A. Gilmour (2007) Assessing biofilm formation by Listeria monocytogenes strains. Food Microbiol. 24: 380-392.

He, D., F. Deng., H. Wang., C. Ke., J. Yan., H. Zhu., W.Lai., M.Song., B.Yang., H.Wang., J.Wang., M. Cong.,B. Ke., X.Deng and H. Ni. (2008). Molecular typing of Listeria monocytogenes isolated from foodstuff in Guangdong province by pulsed-field gel electrophoresis, Zhonghua Liu Xing Bing Xue Za Zhi. 29(1): 38-43.

Henke,D.,S.Rupp and V. Gaschen (2015) Listeria monocytogenes spreads with in the brain by actin based intra axonal migration. Infect. Immun. 83: 2409-2419.

Hofer, E., R. Ribeiro and D.P. Feitosa (2000). Species and serovars of the genus Listeria isolated from different sources in Brazil from 1971 to 1997. Mem.Inst. Oswaldo Cruz.95(5): 615620.

Jallewar, P.K., D.R.Kalorey., N.V Kurkure., V.V.Pande and S.B. Barbuddhe (2007) Genotypic characterization of Listeria spp. isolated from fresh water fish. Int. J. Food Microbiol.114:20-123.

Jassan, V., Jacxsens, L., Luning, P., Rajkovic, A., Uyttendaele, M. (2010) Alternative microbial method: An overview and selection criteria. Food Control. 27: 710-730.

Jaton, K., R. Sahli and J. Bille (1992) Development of PCR assays for detection of Listeria monocytogenes in clinical CSF samples. J. Clin. Microbiol. 30: 1131-1136.

Jeffers, G. T., J. L. Bruce, P. L. McDonough, J. Scarlett, K. J. Boor,and M. Wiedmann (2001). Comparative genetic characterization of Listeria monocytogenes isolates from human and animal listeriosis cases.Microbiology. 147:1095-1104.

Jeong, D. K. and J. F. Frank. (1994) Growth of Listeria monocytogenes at $10^{\circ} \mathrm{C}$ in biofilms with micro-organisms isolated from meat and dairy processing environments. J. Food Prot. 57:576586.

Kalorey, D.R., N.V. Kurkure., S.R. Warke., D.B. Rawool., S.V.S. Malik and S.B. Barbuddhe (2006) Isolation of pathogenic Listeria monocytogenes in faeces of wild animals in captivity. Comp. Immunol. Microbiol. Infect. Dis. 29: 295-300.

Kalorey D.R., S.R. Warke., N.V.Kurkure., D.B Rawool and S.B. Barbuddhe (2008) Listeria species in bovine raw milk: A large survey of Central India. Food Control. 19: 109-112.

Karunasagar, I and I. Karunasagar (2000). Listeria in tropical fish and fishery products.Int. J. Food Microbiol. 62, 
177-181.

Kaur S., S.V.S.Malik, V.M. Vaidya and S.B. Barbuddhe (2006) Listeria monocytogenes in spontaneous abortion in human and its detection by multiplex PCR. J. Appl. Microbiol. 1738-41.

Kaur, S., S.V.S. Malik., V. Vaidya and S. Barbuddhe (2007). Listeria monocytogenes in spontaneous abortions in humans and its detection by multiplex PCR. J. Appl. Microbiol. 103(5): 1889-96.

Kela, E. and P. Holmström (2001) Infectious diseases in Finland 2000. Publications of the National Public Health Institute. KTL B 10/2001.27.

Kessel, J., J. Van., S. Karns., L. Gorski., B. J. McCluskey and M. L. Perdue (2004). Prevalence of Salmonellae, Listeria monocytogenes, and Fecal Coliforms in Bulk Tank Milk on US Dairies J. Dairy Sci. 87:2822-2830.

Kiarsfel, A. D., P. L. Goossens and P. Cossart (1994) Five Listeria monocytogenes genes preferentially expressed in infected mammalian cells: plcA, purH, purD, pyrE and an arginino abcgene, arp. J. Mol. Microbiol. 13: 585-597.

Kocks, C., E. M. Gouin., P. Tabouret, H. Berche., Ohayon and P. Cossart, (1992). L. monocytogenes-induced actin assembly requires the actA gene product, a surface product, a surface protein. Cell.68: 521-531.

Kohler, S., M. Leimeister-Wachter., T. Chakraborty., F. Lottspeich and W. Goebel (1990). The gene coding for p60 of Listeria monocytogenes and its use as specific probe for Listeria monocytogenes. Infect. Immun. 58: 1943-1950.

Kuhn, M. and W. Goebel (1989) Identification of an extracellular protein of Listeria monocytogenes possibly involved in intracellular uptake by mammalian
Cells.Infect.Immun. 57: 55-61.

Kumar, A.V.J., C. Latha., B. Sunil and V.R. Dhanya (2014) Comparison of different cultural techniques in isolation of L. monocytogenes from various samples J. Food borne and Zoonotic Dis. 2(1): 10-14.

Kumar, C.G and S.K. Anand (1998) Significance of microbial biofilms in food industry: a review. Int. J. Food Microbiol. 42: 9-27.

Kumar, S., A. Parvathi., J. George., G. Krohne, I. Karunasagar and I Karunasagar (2009). A study on the effects of some laboratory-derived genetic mutations on biofilm formation by Listeria monocytogenes. World J. Microbiol.Biotechnol. 25: 527-531.

Latorre, A, J. VanKessel., J. Karns., M.Zurakowski., A.Pradhan., K. Boor., B.Jayarao, B. Houser., C. Daugherty and Y. Schukken (2010). Biofilm in milking equipment on a dairy farm as a potential source of bulk tank milk contamination with Listeria monocytogenes. J. Dairy Sci. 93(6): 2792-802.

Lawrence, L. and A. Gilmour (1994). Incidence of Listeria spp. and Listeria monocytogenesin a poultry processing environment and in poultry products and their rapid confirmation by multiplex PCR. Appl. Environ. Microbiol. 60(12): 4600-4.

Lázaro,D.R., M. Marta Hernandez., M. Scortti,T. Esteve., A. Jose', B. Vázquez and Maria Pla (2004). Quantitative Detection of Listeria monocytogenes and Listeria innocua by Real-Time PCR: Assessment of hly, iap, and lin02483 Targets and AmpliFluor Technology. Appl. Environ. Microbiol. Pp. 1366-1377.

Leite, R.M.A. Leite, S.S. Rodrigues Ferreira., G. Ribeiro, C. Jacquet and P. Martin (2006). Comparative characterization 
of L. monocytogenes isolated from Portuguese farm house ewe's cheeses and from humans Int. $\mathbf{J}$ Food Microbiol. 106: 111-121.

Lemon, K., D. Higgins and R. Kolte. (2007). Flagellar motility is critical for Listeria monocytogenes biofilm formation. J. Bacteriol. 189(12): 4418-24.

Lhopital, S., J. Marly, P. Pardon, and P. Berche (1993) Kinetics of antibody production against listeriolysin-O in sheep with Listeriosis. J. Clin. Microbiol. 31: 1537-1540.

Liu, D. (2008) Preparation of Listeria monocytogenes specimens for Molecular detection and Identification.Int.J Food Microbiol. 122: 229-242.

Lukinmaa, S., M. Miettinen.,U.M. Nakari., H. Korkeala and A. Siitonen (2003) Listeria monocytogenes isolates from invasive infections: variation of sero and genotypes during an 11-year period in Finland. J.Clin. Microbiol. 41(4): 1694-1700.

Malik, S.V.S., S.B. Barbuddhe and S.P. Chaudhari (2002) Listeric infections in humans and animals in the Indian subcontinent: a review. Trop Anim Hlth Pro. 34: 359-81.

Mandal, P. K., A. K. Biswas, K. Choi and U.K. Pal. (2011) Methods for rapid detection of foodborne pathogens: an overview. Am. J. Food. Technol. 6: 87-102. 10.3923/ajft.2011.87.102.

Manoj,Y.B., G.M. Rosaling and I.Karunasagar (1991) Listeria spp. in fish and fishhandling areas, Mangalore, India. Asian Fish. Sci. 4: 119-122.

Mata, M. T., F. Baquero and Perez-Diaz, J. C. (2000).A multidrug efflux transporter in Listeria monocytogenes.FEMS Microbiol.Lett. 187: 185-188. doi: 10.1111/j.1574-968.2000.tb09158.

McLauchlin, J.(1996). The role of Public Health Laboratory Service in England and Wales in the investigation of human listeriosis during the 1980s and 1990s. Food Control. 7: 235-239.

Meloni, D., R. Mazza., F. Piras., S. Lamon., S. Consolati., A. Ureddu and R. Mazzette (2012). The biofilm formation ability of Listeria monocytogenes isolated from meat, poultry, fish and processing plant environments is related to serotype and pathogenic profile of the strains, Vety. Sci. Devel. 2(1). https://doi.org/10.4081/vsd.4012.

Mereghetti, L., R. Quentin., N. Marquet-Van Der Mee and A. Audurier (2000). Low sensitivity of Listeria monocytogenes to quaternary ammonium compounds. Appl. Environ. Microbiol. 66(11): 5083-6.

Miettinen, $\mathrm{H}$ and G. Wirtanen (2005) Prevalence and location of Listeria monocytogenes in farmed rainbow trout. Int. J. Food Microbiol. 104(2): 135-43.

Moharem, A. S., A.P.C. Raj and G.R. Janardhana (2007).Incidence of Listeria spp. in seafood products of Mysore, India. J. Food Safety. 27: 362 -372 .

Moriishi, K., M. Terao., M. Koura and S. Inoue (1998) Sequence analysis of the actA gene of Listeria monocytogenes isolated from human. Microbiol. Immunol.42 (2): 129-132.

Moser, J., B. Gerstel and J. E. W. Meyer (1997). Crystal structure of the phosphatidylinositol-specific

phospholipase-C from the human pathogen Listeriamonocytogenes. J. Mol. Biol. 273: 269-282.

Mullapudi, S., R. Siletzky and S. Kathariou (2008). Heavy - metal and benzalkonium chloride resistance of Listeriamonocytogenes isolates from the environment of turkey -processing plants. Appl. Environ. Microbiol. 74(5): 1464-8. 
Murray, E.G.D., R.A. Webb and M.B.R. Swann. (1926) A disease of rabbits characteristics by a large mononuclear leucocytosis caused by a hitherto underscribed bacillus bacterium $L$. monocytogenes (N.Sp.). J. Path. Bacteriol. 29: 407-409.

Najand, M. L., M. Kianpour., M. Sami and M. Jajarmi (2015) Prevalence of Listeria monocytogenes in raw milk in Kerman, Iran. Vet. Res. Forum. 6(3): 223-6.

Nayak, D.N., C.V. Savalia., I.H. Kalyani., R. Kumar and D. P. Kshirsagar (2015) Isolation, identification and characterization of Listeria spp. from various animal origin foods.Vet. World. 8(6): 695-701.

Negi M., J. Vergis., D. Vijay., P. Dhaka., S.V. Malik., A. Kumar., K.V. Poharkar., S.P. Doijad., S.B.Barbuddhe., P.W. Ramteke and D.B. Rawool (2015) Genetic diversity, virulence potential and antimicrobial susceptibility of Listeria monocytogenes recovered from different sources in India. Pathog Dis:73. doi:10.1093/femspd/ftv093.

Niederhauser, C., U. Candrian., C. Hofelein., M. Jermini., H.P. Buhler and J. Luthy (1992) Use of polymerase chain reaction for detection of Listeria monocytogenes in food. Appl. Environ. Microbiol. 58: 1564-1568.

Nightingale, K.K., Y.H. Schukken., C.R. Nightingale., E.D. Fortes, A.J. Ho., Z. Her., Y.T. Grohn, P.L. McDonough, M. Wiedmann (2004) Ecology of transmission of Listeria monocytogenes infecting ruminants and in the farm environment. Appl. Environ. Microbiol. 70: 4458-4467. doi: 10.1128/AEM.

Nightingale, K.K., E.D. Fortes., A.J. Ho., Y.H. Schukken., Y.T. Grohn., and M. Wiedmann (2005) Evaluation of farm management practices as risk factors for clinical listeriosis and fecal shedding of Listeria monocytogenes in ruminants. J. Am. Vet. Med. Assoc. 227: 1808-14. 10.2460/javma.2005. 227.1808.

Norwood, D and A. Gilmour (2001). The differential adherence capabilities of two Listeria monocytogenes strains in monoculture and multispecies biofilms as a function of temperature. Lett. Appl. Microbiol. 33(4): 320-4.

O' Grady, J., S. Sedano Balbás., M.Maher., T.Smith and T. Barry (2008) Rapid real -time PCR detection of Listeria monocytogenes in enriched food samples based on the ssrA gene, a novel diagnostic target. Food Microbiol. 25: 75 -84.

O.I.E. Office, Internationale des epizooties (World Health Organization for animals) 2008 Manual of Diagnostic Tests and Vaccines for Terrestrial Animals (CHAPTER 2). 9.7: Listeria monocytogenes. 201.

Okwumabua, O., O'Connor, M., Shull, E., Strelow, K., Hamacher, M., Kurzynski, T., Warshauer, D (2005) Characterization of Listeria monocytogenes isolates from food, animal clinical cases: PFGE pattern similarity to strains from human listeriosis cases. FEMS Microbiology Lett. 249: 275-281.

Omiccioli, E., G.Amagliani., G.Brandi and M.Magnani (2009) A new platform for Real-Time PCR detection of Salmonella spp., Listeria monocytogenes and Escherichia coli O157 in milk. Food Microbiol. 26 : 615-622.

Parihar, V.S., S.B. Barbuddhe., E.B. Chakurkar., M.L. Danielsson-Tham., W. Tham (2007) Isolation of Listeria species from farm bulk milk at the receiving dairy plant and cervicovaginal swabs.J. Comp. Microbiol. 
Immunol.and Infect. Dis. 281 -28 2.

Park, S., B. Szonyi., R.Gautam, K. Nightingale, J. Anciso and R. Ivanek, (2012). Risk factors for microbial contamination in fruits and vegetables at the preharvest level: a systematic review. J. Food Prot. 75(11): 2055-81.

Parsek, M.R. and P.K.Singh. (2003). Bacterial biofilms: an emerging link to disease pathogenesis. Annu. Rev. Microbiol. 57: 677-701.

Paziak-Domanska, B., E.Bogulawska., M. Wiekowska-Szakiel, R. Kotlowski, B. Rozalska, M.Chmiela, J. Kur, W. Dabrowski and W. Rudnicka (1999) Evaluation of the API test, phosphatidylinositol-specific

phospholipase $\mathrm{C}$ activity and PCR method in identification of Listeria monocytogenes in meat foods. FEMS Microbiol. Lett. 171: 209-214.

Pednekar M.D., A.S. Kamat and H.R. Adhikari (1997) Incidence of Listeria species in milk and milk products. Indian J. Dairy Sci. 50: 142-151.

Piednoir, B. E., N. Botteldoorn., M.Yde, J.Mahillon and N. Roosens (2013) Development and validation of qualitative SYBR ${ }^{\circledR}$ Green real -time PCR for detection and discrimination of Listeria spp. and Listeria monocytogenes. Appl. Microbiol. Biotechnol. 97(9): 4021-37.

Pritchard T.J and C.W. Donnelly (1999) Combined secondary enrichment of primary enrichment broths increases Listeria detection. J. Food Prot. 62: 532-535.

Rakic-Martinez, M., Drevets, D., Dutta, V., Katic, V. and Kathariou, S. (2011) Listeria monocytogenes strains selected on ciprofloxacin or the disinfectant benzalkonium chloride exhibit reduced susceptibility to ciprofloxacin, gentamicin, benzalkonium chloride and other toxic compounds. Appl. and Environ. Microbiol. 77(24): 8714-21.

Raorane, A, S. Doijad., S. Katkar., A. Pathak., K. Poharkar, Z. Dubal and S. Barbuddhe (2014) Prevalence of Listeria spp. in Animals and Associated Environment.Adv. in animal and Vety. Sci. 2(2): 81-85.

Rawool, D.B., Malik S.V, I.Shakuntala., A.M. Sahare and S.B. Barbuddhe (2007) Detection of multiple virulenceassociated genes in Listeria monocytogenes isolated from bovine mastitis cases. Int. J. Food Microbiol. 113(2):201-7.

Rocourt, J. (1999). The genus Listeria and Listeria monocytogenes: Phylogenetic position, taxonomy and identification, p.1-20. In E.T. Pyser and E.H. Marth (ed.), Listeria, listeriosis, food safety, and food safety, $2^{\text {nd }}$ ed. Marcel Dekker Inc., New York, N.Y.

Rocourt, J and P. Cossart (1997). Listeria monocytogenes. 337-352. In M. P. Doyle, L. R.

Rodríguez, G., A. Lama., R. Rodríguez., A. Jiménez, A., R. Guillén and B.J. Fernández-(2008) Olive stone an attractive source of bioactive and valuable compounds. Bioresource Technol. 99 (13): 5261-5269.

Romanova, N., P. Wolffs., L. Brovko and M. Griffiths (2006) Role of Efflux Pumps in Adaptation and Resistance of Listeria monocytogenes to Benzalkonium Chloride. Appl. Environ. Microbiol. 72(5): 3498-3503.

Rossen, L.,Kim Holmstrøm., J.E. Olsen and O.F. Rasmussen (1991) A rapid polymerase chain reaction (PCR) based assay for the identification of Listeria monocytogenes in food samples. Int. J. Food Microbiol. 14(2): 145-51.

Rossmanith P., M. Krassnig., M. Wagner and Hein I (2006). Detection of Listeria 
monocytogenes in food using a combined enrichment/real -time PCR method targeting the prfA gene. Res. Microbiol. 157: 763-771.

Sallen, B.A., S. Rajoharison., S. Desverenne., F. Quinn and C. Mabilat (1996) Comparative analysis of $16 \mathrm{~S}$ and $23 \mathrm{~S}$ rRNA sequences of Listeria Species. Int. J. Syst. Bacteriol. 46: 669-674.

Santorum, P., R. Garcia., V. Lopez and J.V. Martinez-Suarez (2012) Review. Dairy farm management and production practices associated with the presence of Listeria monocytogenes in raw milk and beef Spanish. J. Agri. Res. 10(2): 360-371.

Sarangi, L.N. and H.K. Panda (2012) Isolation, Characterization and Antibiotic Sensitivity Test of Pathogenic Listeria Species in Livestock, Poultry and Farm Environment of Odisha. Indian J. Anim. Res. 46(3): 242 - 247.

Sawant L., S. Kaur, R. S. Aulakh and J P S GILL (2016). Molecular characterization of Listeria monocytogenes in bovine milk and evaluating the sensitivity of PCR for direct detection in milk. J. Animal Sci. 86(5): 512-517.

Scallan, E., R. M., Hoekstra, F. J., Angulo, R. V Tauxe., M.-A., Widdowson, S. L Roy., Jones, J. L. and P.M. Griffin (2011) Foodborne illness acquired in the United States-major pathogens. Emerg Infect. Dis 17: 7-15.

Schlegelova, J., V. Babak., E. Klimova., J. Lukasova., P. Navratilova, A. Sustackova and I. Sediva. (2002) Prevalence of and resistance to antimicrobial drugs in selected microbial species isolated from bulk milk samples. J. Vet. Med. 49: 216-225.

Schuchat, A., K.A. Deaver., J.D. Wenger., B.D. Plikaytis., L. Mascola., R.W. Pinner., A.L. Reingold and C.V.
Broome (1992) Role of foods in sporadic listeriosis: I. Case-control study of dietary risk factors. The Listeria Study Group. JAMA. 267: 2041-2045.

Sela S., S. Frank., E. Belausov and R. Pinto (2006) A Mutation in the luxS gene influences Listeria monocytogenes biofilm formation. Appl. Environ Microbiol. 72: 5653-5658 doi:10.1128/AEM.00048-06.

Shakuntala, I., S. V. S. Malik, S. B. Barbuddhe and D. B.Rawool (2006). Isolation of Listeria monocytogenes from buffaloes with reproductive disorders and its confirmation by polymerase chain reaction. Vety. Microbiol. 117: 229-234.

Sheridan, J.J., G. Duffy., D.A. McDowell and I.S. Blair (1994) The occurrence and initial numbers of Listeria in Irish meat and fish products, and the recovery of injured cells from frozen products. Int. J. Food Microbiol. 22: 105-113.

Shoukat, S., S.V.S. Malik, D.B. Rawool., A. Kumar., S. Kumar, S. Shrivastava., S.B.Barbuddhe., D. Das and S. Das (2014). A study on detection of pathogenic Listeria monocytogenes in ovines of Kashmir region having abortion or history of abortion.proceeding of the National Academy of sciences India. Sect B Biol Sci. 84: 311-316.

Silva, T. M. A., R. G. De Oliveira., J. P. Da Silva Mol., M. N. Xavier., T. A. Da Paixão., A. Cortez., M. B. Heinemann, L.J. Richtzenhain., A.P. Lage and R. de Lima SantosI (2009) Etiologic diagnosis of bovine infectious abortion by PCR. Ciência Rural, Santa Maria. 39(9): 2563- 2570.

Slama, R. B., K. Bekir., H. Miladi., A. Noumi and A. Bakhrouf (2012) Adhesive ability and biofilm metabolic activity of Listeria monocytogenes strains 
before and after cold stress. Afr. $J$.

Biotechnol. 11: 12475-12482.

10.5897/AJB11.3939.

Smith, C.W. and J.F. Metzger (1962) Demonstration of a Capsular Structure on

Listeria monocytogenes.Pathologia.et.Microbio logia.25: 499-506.

Smith, C.J., and A.M. Osborn (2009) Advantages and limitations of quantitative PCR (Q-PCR)-based approaches in microbial ecology.FEMS Microbiol. Ecol. 67: 620.

Smith, G. A., H. Marques and H. Jones (1995) The two distinct phospholipases $\mathrm{C}$ of Listeria monocytogenes have overlapping roles in escape from a vacuole and cell-to-cell spread. Infect. Immun. 63:4231-4237.

Sonegaonka, A. S. (2009) Molecular Characterization of $L$. monocytogenes of human and animal origin. M.V.Sc. Thesis submitted to Maharashtra Animal \& Fishery Sciences University, Nagpur.

Soni, D.K., R. K. Singh., D.V.Singh and S.K. Dubey (2013) Characterization of Listeria monocytogenes isolated from Ganges water, human clinical and milk samples at Varanasi, India. Infect. Genet. Evol.14:83-91.

Soni, D.K., M. Singh., V. D. Singh and S.K. Dubey (2014) Virulence and genotypic characterization of Listeria monocytogenes isolated from vegetable and soil samples. BMC Microbial. 14:241. doi: 10.1186/s12866-014-0241-3.

Srivastava, N.C., S.K. Gupta and P.K. Uppal (1985). Listeria monocytogenes infection in infertile cows, Ind. Vet. J. 62: 545-547.

Stepanovic S., I. Cirkovic, L. Ranin and M. Svabic- Vlahovic (2004).Biofilm formation by Salmonella spp. and
Listeria monocytogenes on plastic surface. Ltt. Appl. Microbial. 38: 428432.

Strachan, N.J.C. and D.I. Gray. (1995). A rapid general method for the identification of PCR products using a fibre-optic biosensor and its application to the detection of Listeria. Lett. Appl. Microbiol. 21(1):5-9.

Suarez, M. and J. A. Vazquez-Boland (2001). The bacterial actin nucleate protein act $\mathrm{A}$ is involved in epithelial cell invasion by Listeria monocytogenes. PUBMED [Accession No. AF103807].

Swaminathan, B., T. Barrett., S.Hunter and R.Tauxe (2001). PulseNet: the molecular subtyping network for foodborne bacterial disease surveillance, United States. Emerg. Infect. Dis. 7(3): 382-9.

To, M. S., S. Favrin., N. Romanova and Griffiths, M. W. (2002).Postadaptational resistance to benzalkonium chloride and subsequent physicochemical modifications of Listeria monocytogenes. Appl. Environ. Microbiol. 68(11): 5258-64.

Ueno, H., K. Yokota and T. Arai (1996) The prevalence of Listeria monocytogenes in the environment of dairy farms. Microbiol.and Immunol. 40: 121-124.

Usman, U.B., Kwaga J., Kabir J. and Bande, F. (2016) Molecular Characterization and Phylogenetic analysis of Listeria monocytogenes isolated from milk and milk products in Kaduna, Nigera. The Canadian J. of infectious diseases and medical Microbiology. 9: 1-7.

Van der Veen, S and Abee, T (2010). Importance of SigB for Listeria monocytogenes static and continuousflow biofilm formation and disinfectant resistance.Appl. Environ. Microbiol. 76: 7854-7860.

Van Houdt., R.and C.W. Michiels (2010) Biofilm formation and the food 
industry, a focus on the bacterial outer surface. J. Appl Microbiol. (4):111731. doi: $10.1111 / \mathrm{j} .1365-$ 2672.2010.04756.x. Epub.

Vanegas, M.C., E.Vásquez., A.J. Martinez. and A.M. Rueda (2009).Detection of Listeria monocytogenes in raw whole milk for human consumptionin Colombia by real-time PCR. Food Control. 20: 430-432.

Vatanyoopaisarn, S., A. Nazli., C. E. Dodd., C.E. Rees and W. M. Waites. (2000). Effect of flagella on initial attachment of Listeria monocytogenes tostainless steel. Appl. Environ. Microbiol.66: 860-863.

Vazquez-Boland, J. A., M. Kuhn., P. Berche., T.Chakraborty., G.Dominguez-Bernal., W. Goebel., B.Gonzalez-Zorn, J. Wehland and J. Kreft (2001)Listeria Pathogenesis and Molecular Virulence Determinants. Clin.Microbiol. Rev. 14(3): 584-640.

Vela, A. I., J. F. Fernandez-Garayzabal., J. A. Vazquez., M. V. Latre, M. M. Blanco., M. A. Moreno., L. de la Fuente., J. Marco., C. Franco., A. Cepeda., A. A. Rodriguez Moure., G. Suarez and L. Dominguez. (2001) Molecular typing by pulsed-field gel electrophoresis of Spanish animal and human Listeria monocytogenes isolates. Appl. Environ. Microbiol. 67: 5840-5843.

Vendeville, A., K. Winzer., K. Heurlier., C. M. Tang and K. R. Hardie. (2005). Making 'sense' of metabolism: autoinducer-2, $\operatorname{luxS}$ and pathogenic bacteria. Nat. Rev. Microbiol. 3:383396.

Vidic, B., S.S. Jevđenić., Ž. Grgić., D. Bugarski and M. Maljković (2007) Infectious abortion in sheep. Biotechnology in Animal Husbandry 23(5-6): $383-389$.

Vilar, M.J., E. Yus., M.C. Sanjuan., F.J. Dieguez and J.L.Rodriguez (2007)
Prevalence and risk factors for Listeria spp. on dairy farms. J. Dairy Sci. 90(11): 5083-5088.

Wang, Y.Y., A.M. Wang and L.Y. Changyun (2014) Rapid and sensitive detection of Listeria monocytogenes by crosspriming amplification of $1 m o 0733$ gene FEMS Microbiology Letters. 361 (1): 43-51. https://doi.org/10.1111/15746968.12610.

Warke, S.R., D.R. Kalorey., N.V.Kurkure and S.B. Barbuddhe (2007).Prevalence and genotypic characterization of Listeria monocytogenes of bovine intramammary origin.Royal Vety. J. 3: 113-117.

Weis, J and H.P.R. Seeliger (1975) Incidence of Listeria monocytogenes in nature. Appl Microbiol.30:29-32.

Wernars, K., K. Heuvelman., S. Notermans., E. Domann., M. Leimeister-Wachter and T. Chakraborty (1992) Suitability of the prfa gene, which encode regulator of virulence genes in Listeria monocytogenes in the identification of pathogenic Listeria spp. Appl. Environ. Microbiol. 58: 765-768.

Wesley, I. V. (1999) Listeriosis in animals.3974.In E. T. Ryser and E. H. Marth (ed.), Listeria, listeriosis, and food safety. Marcel Dekker, New York.

Wesley, I. V., K. M. Harmon., J. S. Dickson and A. R. Schwartz (2002) Application of a multiplex polymerase chain reaction assay for the simultaneous confirmation of Listeria monocytogenes and other Listeria species in turkey sample surveillance. J.Food Prot. 65(5): 780-5.

WHO (2002) Food safety and foodborne illness.Accessed May 12, 2005.

Wiedmann M., J. Czajka., N. Bsat., M. Bodis., M.C. Smith., T.J. Divers and C.A. Batt (1994) Diagnosis and epidemiological association of Listeria monocytogenes strains in two outbreaks of listerial 
encephalitis in small ruminants. J. Clin. Microbiol., 32: 991-996.

Wiedmann, M., J.L. Bruce., C. Keating., A.E. Johnson., P.L. McDonough and C.A. Batt (1997) Ribotypes and virulence gene polymorphisms suggest three distinct Listeria monocytogenes lineages with differences in pathogenic potential. Infection and Immunity 65 : 2707-2716.

Winter, P., F. Schilcher., Z. Bago., D. Schoder., M. Egerbacher., W. Baumgartner and M. Wagner (2004) Clinical and histopathological aspects of naturally occurring mastitis caused by Listeria monocytogenes in cattle and ewes. Zoonosis and Public Health 51(4): 176-179.

Wojciech, L., K. Kowalczyk., Z. Staroniewicz., K. Kosek., J. Molenda and M. Ugorskim (2004) Genotypic Characterization of Listeria monocytogenes isolated from foodstuffs and farm animals in Poland. Bull Vet. Inst. Pulawy. 48: 427-435.

Yadav, M.M., A. Roy., B. Bhanderi., C. Joshi (2010). Pheno-genotypic characterization of Listeria monocytogenes from bovine clinical mastitis.Buff. Bull. 29: 29 - 38.

Yadav, M.M., A.Roy., B.Bhandari and R.G. Jain (2011) Prevalence of Listeria Species including L. monocytogenes from apparently healthy animals at Baroda Zoo, Gujarat State, India. J. threatened Taxa. 3(7): 1929-1935.

Yang, H., L. Qu., A,N. Wimbrow., X. Jiang and Y.Sun (2007) Rapid detection of Listeria monocytogenes by nanoparticle-based immunomagnetic separation and real-time PCR. Int. J. Food Microbiol. 118: 132-138.

Yde, M and A. Genicot (2004) Use of PFGE to characterize clonal relationships among Belgian clinical isolates of $L$. monocytogenes. J. Medi. Microbiol.53: 399-402.

Yong, S.J., F. Joseph., R. E.Frank., Brackett and Chen, J. (2003) Polymerase Chain Reaction Detection of Listeriamonocytogenes on Frankfurters Using Oligonucleotide Primers Targeting the Genes Encoding Internalin AB. J. Food.Prot. 66 (2): 237-241.

Yoshida, T., Y. Kato., M.Sato and K. Hirai (1998) Sources and routes of contamination of raw milk with Listeria monocytogenes and its control. J. Vety. Medi Sci. 60: 1165-1168.

Zhang, Y., E. Yeh., G. Hall., J. Cripe., A.A. Bhagwat and J. Meng (2007). Characterization of Listeria monocytogenes isolated from retail foods. Intl. J. Food Microbiol. 113: 4753.

\section{How to cite this article:}

Shubhangi Warke and Ingle, V.C. 2019. Incidence of Listeria monocytogenes in Bovine Environment with Respect to Phenotypic and Genotypic Characterization: A Review. Int.J.Curr.Microbiol.App.Sci. 8(11): 2611-2637. doi: https://doi.org/10.20546/ijcmas.2019.811.302 